Nowoczesne Systemy Zarządzania

Zeszyt 15 (2020), nr 3 (lipiec-wrzesień)

ISSN 1896-9380, s. 63-74

DOI: $10.37055 / \mathrm{nsz} / 132942$

Modern Management Systems

Volume 15 (2020), No. 3 (July-September)

ISSN 1896-9380, pp. 63-74

DOI: $10.37055 / \mathrm{nsz} / 132942$
Instytut Organizacji i Zarządzania Wydział Bezpieczeństwa, Logistyki i Zarządzania

Wojskowa Akademia Techniczna

w Warszawie

Institute of Organization and Management Faculty of Security, Logistics and Management Military University of Technology

\title{
Net Generation's Customer Experience During a Pandemic
}

\section{Doświadczenie klienckie netgeneracji w okresie pandemii}

\author{
Wioletta Wereda \\ Military University of Technology \\ Faculty of Security, Logistics and Management \\ wioletta.wereda@wat.edu.pl, ORCID: 0000-0002-6948-0239 \\ Florina Pinzaru \\ National University of Political Studies and Public Administration, Bucharest, Romania \\ Faculty of Management, florina.pinzaru@facultateademanagement.ro
}

ORCID: 0000-0002-8371-5284

\begin{abstract}
The article presents the aspect of netgeneration client experience during a pandemic in terms of research by research companies. The aim of this article is to define the concept of netgeneration and the customer's experience during a pandemic. In today's marketplace, customers around the world have the belief that they will live differently in the near future as a pandemic has turned their buying experience. It should be noted that the significant determinants of the new reality seem to be greater uncertainty, less sense of security during shopping and a limited range of face-to-face sales opportunities. Consumers, therefore, can expect brands that I interact with - digitally or as restrictions are relaxed physically - to provide them with better, safer and more free interaction at a lower cost. In the modern world, there is a strong digital activism / socialism (so-called cyberactivism), i.e. a social movement in which citizens want to influence social, economic and political reality using ICT tools. In connection with this movement, one can define the development of netgeneration, which highly values the rights of the individual, independence and freedom of action, opposing institutions, including business ones, which try to limit them, and has a strong sense of common good and socio-civic responsibility, and therefore its customer experiences mainly are related to electronic purchases.
\end{abstract}

Keywords: customer experience, netgeneration, purchasing behaviour, pandemic 
Abstrakt. Artykuł prezentuje aspekt doświadczenia klienta netgeneracji w okresie pandemii w aspekcie badań firm badawczych. Celem artykułu jest określenie pojęcia netgeneracji oraz doświadczenia klienta w czasie pandemii. Na współczesnym rynku klienci na całym świecie są przekonani, że w najbliższej przyszłości będą żyć inaczej, ponieważ pandemia zmieniła ich doświadczenia zakupowe. Należy zauważyć, że istotnymi wyznacznikami nowej rzeczywistości są: większa niepewność, mniejsze poczucie bezpieczeństwa w trakcie zakupów oraz ograniczony zakres możliwości sprzedaży face-to-face. Konsumenci zatem mogą oczekiwać, że marki, z którymi będą wchodzić w interakcje - cyfrowo lub w miarę poluzowania obostrzeń fizycznie - zapewnią im lepszą, bezpieczniejszą i bardziej swobodną interakcję przy niższych kosztach. We współczesnym świecie zauważa się silny cyfrowy aktywizm/socjalizm (tzw. cyberaktywizm), czyli ruch społeczny, w którym obywatele za pomocą narzędzi ICT chcą wpływać na społeczną, gospodarczą i polityczną rzeczywistość. W związku z tym ruchem można określić rozwój netgeneracji, która wysoko ceni prawa jednostki, niezależność i swobodę działania, sprzeciwiając się instytucjom, w tym biznesowym, które próbują je ograniczać, oraz ma silne poczucie wspólnego dobra i odpowiedzialności społeczno-obywatelskiej - dlatego jej doświadczenia klienckie związane są głównie z zakupami elektronicznymi.

Słowa kluczowe: doświadczenie klienckie, netgeneracja, zachowania zakupowe, pandemia

\section{Introduction}

Digital progress, especially the fast-growing Internet and its application, has made it necessary for consumers to adapt to the prevailing trends that shape the market. Not only has the customer's behaviour changed, but also the importance of the customer in the modern world that has experienced a pandemic. The emergence of ICT tools and electronic development has resulted in the emergence of a new type of client called "netizen" and an entire generation, i.e. netgeneration. It should be emphasized that the contemporary web generation is not a passive recipient of mass consumer culture, but is becoming its co-creator. What's more, this generation is curious about the world, searches for and verifies information on virtually every topic, willingly sharing the acquired knowledge and not hesitating to express its own opinions out loud. Generation $\mathrm{Z}$ in particular are creative and active people who want to participate in shaping the reality around them. In the era of the heyday of the Internet and its growing importance among consumers, there has been a transformation of the environment, which caused an impulse to search for alternative methods of satisfying one's own shopping needs. The development of the market assortment, the developing technology and the growing importance of information and its power to influence consumer behaviour also contributed to the change in the environment (Małysa-Kaleta, 2016, p. 144). In the 90s of the twentieth century, the field of computer science was close only to IT specialists and users who were able to use the network in a professional way. Currently, technology is undergoing a revolution and for today's users, who increasingly identify with the word "citizen", using e-services has become their everyday life. Currently, mobile devices that dominate the computer market are undergoing a very significant revolution. Mobile phones have become an everyday accessory for users, just like everyday items - watches or wallets. Now everything can be replaced with a Smartphone (Ronchi, 2019, p. 5). In addition, the pandemic situation forced many customers to enter the virtual world in terms of work, study or shopping. 


\section{Evolution and characteristics of netgeneration}

The social changes we have been experiencing since the second decade of the 21 st century are shaping a new digital socialism, in which the masses are equipped with the means of production and self-organize, creating the so-called hyperarchic structures, work for free towards a common goal, and then share and use the "fruits" of cooperation free of charge (Kelly, 1995, p. 22-23; Shirky, 2010, p. 130-135; Roszkowska-Menkes, 2015, p. 99-100). In addition, online communities that are capable of peer-to-peer communication and self-organization in real time are reminiscent of bees or shoals of fish. In other words, online communities can be defined as a virtual community, a swarm system, or a hierarchical system. These communities are characterized by several principles (Kelly, 1995; Roszkowska-Menkes, 2015, p. 98; Płoszajski, 2012):

1. Lack of imposed central control - management is distributed among system components.

2. Autonomy of component elements - each element reacts individually according to its own rules, adequately to the state of the local environment.

3. High connection of systems - there is a very large number of connections between the autonomous system components, but they are not connected to the central system node; the structure being formed is a decentralized peer-to-peer network.

4. Horizontal causality - elements interact in a network and non-linear way, "A" indirectly affects everything else, everything else indirectly affects "A"; with regard to events taking place within the system, it is impossible to determine what exactly triggered them.

5. Ad hoc - a virtual community is created for the duration of a specific task, after which it is dissolved; its members being; often participants in many communities at the same time, they are connected for a short moment by common interest, and then they disperse to new, again temporary, tasks.

6. Flash crowd nature - the number of system elements changes quickly and to a large extent.

7. Scalability - the system has the ability to accept large changes in the workload without detriment to their implementation.

Therefore, the young generation, brought up in the digital world, which many authors call netgeneration, plays a major role in the Internet society (Tapsctott, 1999). It should be emphasized that for young people with "cyber mentality", where the virtual world is as real as the off-screen. Online activity is closely related to activities carried out in the real world, and on- and offline realities constantly interpenetrate (Roszkowska-Menkes, 2015, p. 105). Tapscott defines netgeneration as the generation of the echo of the post-war baby boom, i.e. people born between 1977 and 1997. According to other authors, people born in 1988-2001 or 1988-1993 are considered 
to be representatives of the network generation. In the literature on the subject, this generation is also often referred to as generation $\mathrm{Y}$, the millennial generation, or generation $\mathrm{C}$ (for content). Many authors define the concept of netgeneration through an even younger generation, i.e. born at the turn of the 20th and 21st centuries (1990-2010), sometimes called generation Z, generation M (from multitasking) or digital natives (Tapscott \& Ticoll, 2003; Wallis, 2006; Palfrey, 2008; Consumers of Tomorrow..., 2011; Roszkowska-Menkes, 2015). In the literature on the subject, you can find many definitions - the selected ones are presented in Table 1.

Table 1. Definitions of netgeneration

\begin{tabular}{|c|c|}
\hline Definition & Author \\
\hline $\begin{array}{l}\text { The generation of youth which is growing up with modern informa- } \\
\text { tion and communication technologies shaping strongly their mental } \\
\text { models, i.e. views on the world around them. While using several } \\
\text { technologies they are learning to develop new skills and exhibiting } \\
\text { new behaviour patterns. }\end{array}$ & Mikulecký et al. (2011) \\
\hline $\begin{array}{l}\text { Known as 'Millennials or digital natives', as they have been subjected } \\
\text { to digital technologies throughout their lives and describes them as } \\
\text { being more technologically prominent compared to older cohorts. }\end{array}$ & $\begin{array}{l}\text { Bombazi Tshazi, Civilcharran } \\
\text { (2020) }\end{array}$ \\
\hline $\begin{array}{l}\text { The generation of individuals who have grown up with computer } \\
\text { technology and the Internet as a commonplace. The distinguishing } \\
\text { mark of this generation is that its members spent their formative } \\
\text { years during the rise of the World Wide Web. They usually have no } \\
\text { memory of (or nostalgia for) pre-Internet history. Most were born } \\
\text { after } 1993 \text {. }\end{array}$ & Jackson et al. (2010) \\
\hline $\begin{array}{l}\text { Individuals born between } 1981 \text { and 1994, whose defining charac- } \\
\text { teristic is their familiarity with the Internet. }\end{array}$ & Level, Hoseth (2008) \\
\hline $\begin{array}{l}\text { Individuals who have grown up with information technology in many } \\
\text { aspects of their lives. These individuals have aptitudes, attitudes, } \\
\text { expectations, and learning styles that reflect the technology-rich } \\
\text { environment in which they were raised. }\end{array}$ & Ragan (2009) \\
\hline $\begin{array}{l}\text { The Net Generation is defined as the population of about } 90 \text { million } \\
\text { young people who have grown up or are growing up in constant con- } \\
\text { tact with digital media and have already been defined by academics } \\
\text { as smart but impatient. }\end{array}$ & Beyers (2009) \\
\hline $\begin{array}{l}\text { A group of people born between the early 1980's and the late 1990's, } \\
\text { into technological advances. }\end{array}$ & $\begin{array}{l}\text { Padrón Moctezuma, Vasquez } \\
\text { Ochoa, Montoya Ramírez } \\
\text { (2016) }\end{array}$ \\
\hline $\begin{array}{l}\text { The net generation are students who were born in the } 1980 \text { s and } \\
\text { later. They have grown with computer and the Internet and been } \\
\text { digitally literate. }\end{array}$ & Kim, Baek (2010) \\
\hline $\begin{array}{l}\text { Young people, usually under } 25 \text { years of age, who rely on Internet } \\
\text { connectivity through wireless technology to communicate quickly } \\
\text { and efficiently both socially and educationally. }\end{array}$ & Garland (2009) \\
\hline
\end{tabular}


cont. Tab. 1

\begin{tabular}{|c|c|}
\hline \multicolumn{1}{|c|}{ Definition } & Author \\
\hline $\begin{array}{c}\text { Refers to the description given to young Americans born from } \\
1976 \text { to 2001. }\end{array}$ & Hricko (2008) \\
\hline $\begin{array}{c}\text { Persons born in the 1980's or later; members of the Net Generation } \\
\text { have never known life without the Internet. }\end{array}$ & $\begin{array}{c}\text { Brinthaupt, Clayton, Draude } \\
\text { (2009) }\end{array}$ \\
\hline $\begin{array}{r}\text { Refers to students who were born after 1980 and were digitally literate. } \\
\text { related technologies. }\end{array}$ & $\begin{array}{c}\text { Ursu, Panisoara, Chirca } \\
\text { (2020) }\end{array}$ \\
\hline $\begin{array}{r}\text { All generations born after 1980 that grew up using the and } \\
\text { With this term students defined as "digital immigrants." Usually this } \\
\text { comes from their utilization with innovative platforms which are } \\
\text { widespread and specifically referred to their needs and demands, } \\
\text { basically for collaboration and communication with others with the } \\
\text { same age in a virtual world. }\end{array}$ & $\begin{array}{c}\text { Daffron, Barse, } \\
\text { (2009) }\end{array}$ \\
\hline
\end{tabular}

Source: Own study based on the literature

One regularity should be noted in the above definitions, which is that representatives of netgeneration have access to the Internet, are educated with technology, are mostly online and are constantly connected to the web. At the same time and through the same medium, they are active in various types of networks, establishing private or business contacts, shopping, contacting friends and family, or fulfilling civic duties, especially during a pandemic. In addition, the culture of the network generation is characterized by ten basic characteristics (Tapsctott, 1999, p. 1409-1411; Roszkowska-Menkes, 2015, p. 105-106):

1. Fierce independence - representatives of the network generation are active seekers and creators of information, not just its passive recipients; have a strong sense of independence and creative autonomy.

2. Emotional and intellectual openness - ICT tools provide young people with unlimited possibilities for self-expression, sharing with a wide audience their thoughts, feelings and experiences, which can also be the subject of open, often painful criticism; Certainly, emotional openness is facilitated by anonymity, which often accompanies online activity.

3. Social inclusion - the Internet is a multicultural environment in which netgeneration gets rid of stereotypes, learns tolerance, builds a global network of contacts and undertakes cooperation.

4. Freedom of speech and strong views - the Internet broadens the horizons of young people, gives them the opportunity to learn about various opinions, ideas, arguments, build their own views and express their own thoughts freely. Access to information and freedom of expression are fundamental rights for netgeneration. 
5. Innovation - the online environment makes it possible to build your own world, change your environment; the innovation of the web generation is additionally driven by the forces of the fifth wave of the computer revolution and the development of Web 2.0.

6. Maturity - largely related to the independence and independence of the network generation.

7. Inquisitiveness - the culture of the network generation is based on curiosity, inquiry and questioning the truth about the surrounding world, as well as the possibility of influencing its shape.

8. Immediacy - the network generation lives in a world of instant action: in the world of real-time communication.

9. Distrust towards corporations - the network generation itself acquires and verifies information about the activities of companies, does not want to be and is not a passive recipient of advertising messages, expects companies to communicate transparently.

10. Verification - the anonymity and diversity of the web forces the Internet generation to constantly verify all information.

On the other hand, when presenting a description of the customer's evolution over the years, it can be noticed that in the last year, the limitations resulting from the COVID-19 pandemic meant that companies are dealing with a new, changed consumer who, by adapting to rapid changes in the environment, has developed new behaviours and habits. Some behaviours were already noticeable before, but the new conditions significantly accelerated them (remote shopping for food categories, using remote forms of entertainment, and so on). Other behaviours are more timeless and long-lasting, in addition, new behaviours and shopping habits appear (remote forms of physical activity at home, remote training). Moreover, the consumer era driven by the digital transformation of individual enterprises and entire industries in the economy enters a new stage - accelerated transformation requiring quick and agile response to customer needs, which in the new reality may change overnight. Five types of client have been identified (Wereda, Woźniak, 2018, pp. 7-8; Raport KPMG, 2020, p. 16):

1. Client 1.0 (before 1950) - a client who chose only certain groups of products was not influenced by advertisements; had an opinion on the products and was guided by their practical application in purchasing choices; he/she rarely used market news; shaping the consumer demand was related to the use of the available production or supply capacities of the enterprise; the customer had little choice and bought the products that were available and the best there was at the time.

2. Client 2.0 (1950-2000) - the principles of this client are still valid, but are now supported by the development of consumerism and traditional marketing; he/she recognizes brands and his/her demand for products and services is strongly driven by marketing; he/she also uses market news advertised in the media; the first concept of the brand appeared. 
3. Client 3.0 (2000-2015) - Client 1.0 and 2.0 principles are noticeable, but the buyer behaviour is extended with the explosion of globalization and the Internet; it is important for this customer to retain him with the brand through various programs, e.g. loyalty programs; the customer pays attention not only to the quality of the product, the brand, but also to the best customer service and individual treatment by suppliers of products and services; defines its purchasing experiences and shares them with the public; customer retention and loyalty are key aspects of the company.

4. Client 4.0 (2016-2020) - is a client whose rules (based on the experience of $1.0,2.0$ and 3.0 clients) are still evolving, but are now complicated thanks to the huge selection, online platforms. Personal goals and creating your own personal brand outweigh marketing. It is the customer who tries to influence and be influenced by other customers, it is the one who applies new ways of working and thinking; that has high expectations, where the customer's journey is his or her unique journey, where companies only participate in enabling them to achieve their goals. This client is an internet user, very demanding, well informed by electronic devices and looking for developing, competitive and innovative approaches to various challenges in various areas of life, such as banking, professional services, automotive and IT services, healthcare, education, utilities (most aspects) production and construction, etc. Influenced by the values represented by Millennials and Generation Z. Client 4.0 is a person who in his/her choices is more driven by personal goals and preferences and is less susceptible to mass marketing messages.

5. Customer 5.0 (from 2021-) - accelerated digitization in the time of the COVID-19 pandemic has caused customers to move to the online world, reducing the number of physical purchases in stores; self-service will dominate in many different ways and the desire for comfort and security will become more and more present in the near future; purchasing patterns change as consumers shift from unnecessary to basic spending; value and price will now be just as important as any other aspect of the experience.

\section{Customer experience during the pandemic}

According to various authors, customer experience is defined as a mixture of the physical image of the organization and the feelings and sensations caused by it consciously or unknowingly at every stage of the customer's contact with the company and the brand, at all points of contact (touch-points). The set of experiences creates an image in the customer's mind, and at the same time the image of the brand and its values, influencing the assessment of the organization's activities and 
the brand, the tendency to enter into closer relationships with the company, and above all, purchasing decisions (Forrester Reasearch, 2016; SAS Institute Inc. 2016; Bernhardt et al., 1998). What is more, Customer Experience (CX) is a complex practice area that requires clear vision, the right tools, and great execution to succeed. Oracle's research recommends thinking about CX in terms of three major areas: Acquisition (A), Retention (R), and Efficiency (E). These areas play a critical role in any business. Describing the processes it should be pointed out that "Acquisition" refers to an organization's ability to increase its customer base. "Retention" is the ability to keep and grow current customers and "Efficiency" allows an organization to do more for its customers with less resources. Each CX practice area has three identified business challenges, adding up to a total of nine CX business challenges for success (Oracle Corporation, 2012) - table 2. Nowadays Customer Experience creates the level of client's trust towards enterprises, the customers risk in contact with sales representatives as well as the safety delivered by enterprises.

Table 2. Customer Experience (CX) Metrics and Key Performance Indicators

\begin{tabular}{|c|c|c|}
\hline $\begin{array}{c}\text { Acquisition } \\
\text { (increase sales) }\end{array}$ & $\begin{array}{c}\text { Retention } \\
\text { (monetize relationships) }\end{array}$ & $\begin{array}{c}\text { Efficiency } \\
\text { (leverage investments) }\end{array}$ \\
\hline Generate more opportunities & Increase share of wallet & Increase ROIC/EVA \\
\hline Increase brand equity & Drive loyalty & Increase productivity \\
\hline Increase market share & Drive advocacy & Decrease cost of operations \\
\hline
\end{tabular}

Source: Oracle Corporation, 2012

The customer experience during the pandemic changed its basic needs, not only of netgeneration but also of older generations. According to a study by KPMG in 2020 , the pandemic recovery period is a time of accelerated, sometimes "forced" transformations, in which myths must be separated from facts about actual regulatory, market and organizational constraints. This is a new time of focusing on a new consumer who will approach purchasing decisions in a more conservative way, where the crisis is not only a threat, but above all an opportunity for many brands. The survey was conducted in the second quarter of 2020 using the CAWI method (Computer-Assisted Web Interview) on a sample of over 5,000 respondents, representative of Polish residents aged over 16. The key conclusions from the study indicate that it affects the current customer experience (Raport KPMG, 2020, pp. 3-6):

1. Personalization and credibility are the two pillars that have the greatest impact on the willingness of customers to recommend a brand. During the pandemic, customers saw organizations put their customers and employee welfare ahead of profit, and aligning experiences with personal circumstances became a key aspect. 
2. Time and effort is another pillar that recorded the highest result in the ranking, while the Expectations pillar recorded the largest increase by nearly $5 \%$. The COVID-19 pandemic has reinforced the need for easy access to products and services, convenience and relevant information, and understanding customer expectations that have become fluid, shaped by the events around them, is an essential part of building a positive experience.

3. Despite the conditions caused by the pandemic, customers rated the experiences offered by brands higher - the Customer Experience Excellence index recorded an increase of $4.3 \%$.

4. Non-food retail remained the leader of the survey among the sectors, for which building the position of the industry providing the best customer experience before the pandemic also allowed to meet the expectations and needs in the new reality.

5. In view of the new conditions for the functioning of individual industries, the highest growth was recorded in the food retail trade and logistics, and the greatest decline in the tourism industry.

6. The time of the pandemic is the time of accelerated digitization. Digital brands make up 3 of the Top 10 highest-rated brands in the entire survey.

Referring to the conclusions of the report, purchasing decisions and propensity to consume, which translate into the level of expenditure, are conditional on the one hand by the actual financial situation of households, as well as by the general level of consumer sentiment. Households whose real situation has not worsened during the pandemic may decide to cut their spending for fear of their financial situation in the near future. Based on the observation of consumer behaviour in different geographic regions, we see differences in the approach to spending - consumers in Germany, France and China report a greater sense of financial security, while consumers in Brazil, Japan, Italy and Spain have stopped unnecessary purchases and have become more conservative limiting ourselves to key expenses. When looking at a large group of consumers who reduced their spending to what was needed during the COVID-19 pandemic (over $50 \%$ of respondents aged 18-54), it was observed that for over $1 / 3$ of this group, the actual financial situation has not changed. Consumers in times of uncertainty hold back unnecessary expenses, manage their finances more carefully and build greater financial security in the event of a deteriorating financial situation. The time of the COVID-19 pandemic has increased the need for easy access to products, services and information. Customers have started using digital channels when shopping more than before. For Polish consumers, trust, in addition to the value for money and ease of purchase, is one of the key purchasing factors that shape the experience. During a pandemic, consumers attach greater importance to the way brands build their credibility. Among the important factors that have gained importance, consumers indicate support for local communities, the brand's attitude to the environment or the brand's approach to employees (Raport KPMG, 2020, pp. 9-11). 


\section{Conclusions}

Summing up, it should be emphasized that for several months there has been a breakthrough change in the basic conditions of the competitive environment that have been shaped in recent years. A high degree of uncertainty, volatility of the regulatory environment or accelerated changes in the sphere of using digital technologies create new rules of competition. Maintaining a competitive advantage and further development requires ongoing monitoring and understanding of changes in many levels of the business environment. One can notice the process of shaping the customer experience by companies in the purchasing process in contemporary reality - Figure 1.

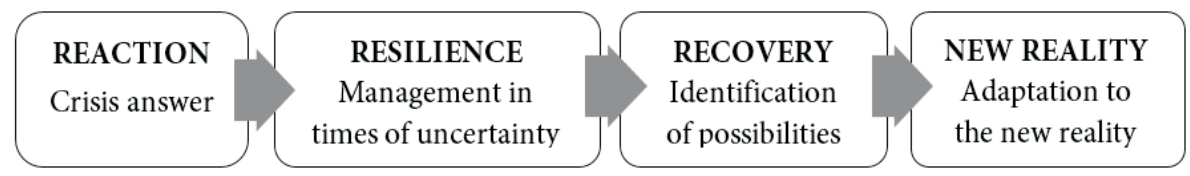

Fig. 1. The road to the new reality - from the beginning of the pandemic to the reality after the crisis Source: Raport KPMG, 2020, p. 14

The road to the new reality consists of several stages, in which enterprises must focus on the key activities at a given moment. The pace of transition from one phase to another depends on the sector and the extent of the restrictions imposed during the different phases of the pandemic. When analyzing customer ratings on the basis of consumer research conducted by KPMG in Poland, it can be observed that the actions typical for the second phase (related to the adaptation of enterprises to the introduced changes) are assessed positively. It is worth noting, however, that subsequent phases (Recovery, New Reality) will require brands to focus on managing customer experiences in a way that builds a competitive advantage in the new conditions.

\section{REFERENCES}

[1] Bernhardt, K.L., Donthu, N., Kennett, P.A., 2000. A Longitudinal Analysis of Satisfaction and Profitability, Journal of Business Research, No. 2963/98.

[2] Beyers, R.N., 2009. A five dimensional model for educating the Net Generation, Educational Technology \& Society, No. 12(4).

[3] Bombazi Tshazi, Z., Civilcharran, S., 2020. Predicting Multi-Generational Technology Adoption Practices in a South African Context: Millennials vs. Generation X, [in:] P. Ndayizigamiye, G. Barlow-Jones, R. Brink, S. Bvuma, R. Minty, S. Mhlongo, Perspectives on ICT4D and Socio-Economic Growth Opportunities in Developing Countries, IGI Global, Harshey, USA.

[4] Brinthaupt, T.M., Clayton, M.A., Draude, B.J., 2009. Barriers to and Strategies for Faculty Integration of IT, [in:] P. Rogers, G. Berg, J. Boettcher, C. Howard, L. Justice, K. Schenk, Encyclopedia of Distance Learning, Second Edition, IGI Global, Harshey, USA. 
[5] Consumers of Tomorrow. Insights and Observations About Generation Z, 2011. Grail Research, November, www2.slideshare.net (10.11.2020).

[6] Daffron, S.R., Barse, A.J., Webster, E., 2009. Key Aspects of Teaching and Learning in the Online Environment, [in:] W.X. Wang, Handbook of Research on E-Learning Applications for Career and Technical Education: Technologies for Vocational Training, IGI Global, Harshey, USA.

[7] Forrester Research, The Business Impact of Customer Experience, Customer Experience Consulting, www.forrester.com (10.12.2016).

[8] Garland, V.E., 2009. Wireless Technologies and Multimedia Literacies, [in:] L.T. Wee Hin, R. Subramaniam, Handbook of Research on New Media Literacy at the K-12 Level: Issues and Challenges, IGI Global, Harshey, USA.

[9] Hricko, M., 2008. Net Generation, [in:] L.A. Tomei, Encyclopedia of Information Technology Curriculum Integration, IGI Global, Harshey, USA.

[10] Jackson, L.A., Fitzgerald, H.A., Eye, A., Zhao, Y., Witt, E.A., 2010. The Digital Divides in the U.S.: Access, Broadband, and Nature of Internet Use, [in:] E. Ferro, Y.K. Dwivedi, J.R. Gil-Garcia, M.D. Williams, Handbook of Research on Overcoming Digital Divides: Constructing an Equitable and Competitive Information Society, IGI Global, Harshey, USA.

[11] Kelly, K., 1995. Out of control. The New Biology of Machines, Social Systemse the Economic World, Basic Books, New York.

[12] Кiм, K., BAEK, Y., 2010. Exploring Ideas and Possibilities of Second Life as an Advanced E-Learning Environment, [in:] H. Yang, S. Chi-Yin Yuen, Handbook of Research on Practices and Outcomes in E-Learning: Issues and Trends, IGI Global, Harshey, USA.

[13] Level, A.V., Hoseth, A.E., 2008. Learning and Teaching with CMC in the U.S. Higher Education Arena, [in:] S. Kelsey, K.St. Amant, Handbook of Research on Computer Mediated Communication (2 Volumes), IGI Global, Harshey, USA.

[14] MaŁysa-Kaleta, A., 2016. Misja konsumenta we współczesnym świecie, Handel Wewnętrzny, $\mathrm{nr} 4$.

[15] MikuleckÝ, P., OlŠEvicová, K., Bureš, V., Mls, K., 2011. Possibilities of Ambient Intelligence and Smart Environments in Educational Institutions, [in:] N. Chong, F. Mastrogiovanni, Handbook of Research on Ambient Intelligence and Smart Environments: Trends and Perspectives, IGI Global, Harshey, USA.

[16] Nicolas, P., 2015. Conceptual Foundations for Interactive Programming Activities with the Conjunction of Scratch4OS and Open Sim, [in:] M. Khosrow-Pour, Encyclopedia of Information Science and Technology, Third Edition, IGI Global, Harshey, USA.

[17] Oracle Corporation, 2012. Customer Experience (CX) Metrics and Key Performance Indicators', on-line leaflet, www.oracle.com (10.12.2016).

[18] Padrón Moctezuma, M.S., Vasquez Ochoa, M.A., Montoya Ramírez, M.S., 2016. Net Generation Features that Enhance Mobile Learning, [in:] L. Briz-Ponce, J.A. Juanes-Méndez, F.J. García-Peñalvo, Handbook of Research on Mobile Devices and Applications in Higher Education Settings, IGI Global, Harshey, USA.

[19] Palfrey, J., Gasser, U., 2008. Born Digital: Understanding the First Generation of Digital Natives, Basic Books, New York.

[20] PŁoszajski, P., 2012. Ruchomy cel: o konieczności redefinicji teorii i praktyki społecznej odpowiedzialności przedsiębiorstw w warunkach nowej gospodarki, [in:] P. Płoszajski (ed.), Społeczna odpowiedzialność biznesu w nowej gospodarce, Wydawnictwo OpenLinks, Warszawa. 
[21] Ragan, L.C., 2009. Operational Performance Guidelines for Online Instructors, [in:] P. Rogers, G. Berg, J. Boettcher, C. Howard, L. Justice, K. Schenk, Encyclopedia of Distance Learning, Second Edition, IGI Global, Harshey, USA.

[22] Raport KPMG, 2020, Doświadczenia klientów w nowej rzeczywistości, www.kpmg.pl (12.12.2020).

[23] Ronchi, A.M., 2019. e-Citizens: Toward a New Model of (Inter)active Citizenry, Springer Nature, Switzerland.

[24] Roszkowska-Menkes, M., 2015. Otwarte innowacje: $w$ poszukiwaniu równowagi, SGH, Warszawa.

[25] SAS Institute InC., 2016. Customer Experience Management. What It Is and Why It Matters, www.sas.com (10.12.2016).

[26] Shirky, C., 2010. Cognitive surplus: Creativity and Generosity in A Connected Age, The Pengium Press, New York.

[27] Tapscotт, D., 1999. Growing Up Digital: The Rise of Net Generation, McGraw Hill (Kindle Edition).

[28] Tapscott, D., Ticoll, D., 2003. The Naked Corporation: How the Age of Transparency Will Revolutionize Business, Free Press.

[29] Ursu, A.S., Panisoara, I.O., Chirca, R.C., 2020. The Changes Brought by Digital Technology to Cognitive Learning, [in:] J.E. Pelet, Handbook of Research on User Experience in Web 2.0 Technologies and Its Impact on Universities and Businesses, IGI Global, Harshey, USA.

[30] Wallis, C., 2006. genM: The Multitasking Generation, Time Magazine, March 27 (10.11.2020).

[31] Wereda, W., Woźniak, J., 2019. Building Relationships with Customer 4.0 in the Era of Marketing 4.0: The Case Study of Innovative Enterprises in Poland, Social Sciences, No. 8(6). 